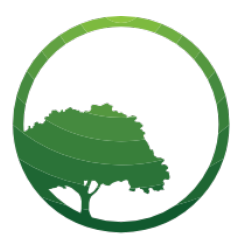

Business \& Social Science IJRBS

\section{Research in Business and Social Science}

IJRBS Vol 8 No 3, Special Issue ISSN: 2147-4478

Contents available at www.ssbfnet.com/ojs

\title{
Analysis of the Effect of Coaching on Teamwork Performance
}

\author{
Neil Aldrin
}

Lecturer of Psychology Faculty, Bhayangkara Jakarta Raya, University

ORCID ID: 0000-0001-8990-4695

\section{Andyan Pradipta Utama}

Faculty of Economic, Persada Indonesia YAI, University

\begin{abstract}
This study aims to examine the effect of coaching on teamwork, using a quantitative approach to test whether there are significant differences. The research sample was 15 employees who joined in one teamwork at the same company. The results show that the correlation between before using coaching and after its use is very strong and significant. So that it can be said that there is a significant difference in teamwork after being given coaching. Thus it is proven that coaching affects teamwork performance. Results are seen three months after coaching is taught. This is intended to see whether it can really be applied to the work team. The results found that there were very significant differences in the work team before and after coaching was taught.
\end{abstract}

Key words: Coaching, Teamwork, Performance, Organizational

JEL classification: L20

Submitted: 20.03.2019 - Accepted: 28.04.2019

\section{Introduction}

In today's rapidly changing economic growth, organizational growth, productivity and continuity are determined by the professional and personal qualifications of employees (Kauffeld, 2010; Salas et al., 2012). Increasing employee productivity is one of the most important goals for any organization. Increasing employee productivity is one of the main goals for any organization, as productive employees would affect the organization's performance as a whole. Increasing employee productivity has been a central issue in previous research whether in manufacturing or service industries, because the increase in employee productivity has an effect on the organizational performance as a whole and give the organization some competitive advantage (Hanaysha, 2016).

Working collaboratively is a process that involves a group of people to reach the goal. This is what is called team work, where teamwork today is very important in an organization. Where each individual is forced to be able to work together in a work team by trying to give the best even in any situation experienced by a 
work team. Every individual in a work team will try to give the best by using the various skills possessed by each individual. This is in line with Aichouni (2005), where individuals cannot do their own work and because help from others is needed. So, the importance of teamwork is needed by the organization. The development of technology in the present is more complex, so the need for team work (Rufus, 1998). As found in his research, Kioko (2018), recommends to all organizations to require employees to work in teams to achieve organizational goals. Team work needs to be appreciated and appreciated because there is strength in the unity that is generated by teamwork.

It is believed that team work can help utilize the skills of workers in an effort to gain a competitive advantage. Organizations focused on developing team work tend to experience many benefits including better and better decision making, flexibility among the workforce and focus on achieving organizational goals with a highly motivated workforce and synergy among team members (Alghamdi \& Bach, 2018). Innovation and creativity can be created when teamwork is prioritized, as well as in making a quality decision, so that the commitment of each member of the work team to the tasks assigned by the organization to them. In its development, the team needs a technique to accelerate in achieving the goals desired by the organization.

Coaching as an intervention, which because of its potential has a variety of applications and heterogeneity of practitioners. In its development a number of merger techniques were used, development and training. Where the initial focus is the determination of the definition of coaching and its boundaries that separate it from counseling and consultation (Grover \& Furnham, 2016). The results and objectives of coaching are certainly different, both from session to session and from individual to individual and during their involvement. Kauffman and Coutu (2009) found out of 140 trainers who stated that the majority of them, 132, said that the focus of their training sessions shifted during their involvement in the session and said a number of reasons; deeper goals, natural evolution, self-awareness, relationships and coaching conditions. Coaching is basically a conversation or dialogue between a coach and participants - in a productive and results-oriented context (Dolot, 2017). Coaching can bring behavior change and help individuals understand how their cognitive and emotional reactions can interfere with effectiveness, performance, and personal well-being (Bluckert, 2005b).

Team performance standards are a goal, in this case contained guidelines in decision making, planning, and how actions are taken. Therefore attention must be focused so as to produce an attention that ultimately leads to thoughts and actions (Mullins, 1996; Ives, 2008). According to Dolot (2017), developing competencies is greatly assisted by coaching such as: more effective team management, communication with other employees, and teamwork.

\section{Literature Review}

\section{Teamwork}

Teams in organizations are indeed formed for all kinds of circumstances. This can be found in organizations to be able to overcome the problems that are being faced by each organization (Lazear and Shaw, 2007). Little chance for teams to think about how they work together to achieve a common goal. Each organization has its own goals, objectives and targets and each team works independently. Sometimes team members have their own understanding and report that they have no chance to get to know other members even though they have worked together for several years. (Woodhead, 2011). Without a forum for collaborative discussion there is no collective approach, which results in frustration when one discipline has done 'their part' and the other does not.

The experimental evidence shown by Landeo and Spier (2015) states that if individuals work in teams, interactions repeat and allow them to work harder. Fahn \& Hakenes, (2017), show that team work can help overcome the problem of self-control, even team work generates technological benefits, implying that individuals are also consistent and prefer to work in teams rather than on individual projects. This is also in line with Bruce and Ricketts (2008), who say that team work is very important among cross-disciplinary groups in order to produce effective, efficient and maximum work.

The relationship between collectivism orientation of teamwork is stronger. Team work orientation is significantly related to personal learning regardless of the degree of appropriateness of perceived value between individual members and other team members (Ghulam, Glavee-geo, \& Rice, 2014). The attitude of collaboration, competence, and culture behind each participating institution and team member is reflected in the team's performance (Wu \& Ya-Hsueh, 2014). Team work will be positively linked to results for organizational goals where team work has a positive effect on organizational performance and how the team implements and can improve efficiency and encourages employees to work smarter and harder (Delarue, Hootegem, Procter, \& Burridge, 2008 ), Benrazavi \& Abu (2013), also considers team work as an important factor that contributes to employee performance. Team work is a reciprocal activity that aims to achieve 
common goals through Engineering involving members of organizations in certain groups to share their knowledge and skills with each other.

Mbinya (2013) shows that the majority of organizations focus on team work in an effort to reach their targets. Previous studies found that teamwork had a significant positive effect on employee productivity and organizational performance. Team members who get the opportunity to learn and apply new skills will have a better attitude towards team work (Jiang, 2010). In addition, Gallie, Zhou, Felstead and Green (2009) confirm that team work enriches performance through increasing the scope of employee use of knowledge, skills and abilities and sharing them with other members. So the team can be described as a group of people who work together to achieve the same goals and objectives for the good of service users and organizations to provide quality services (Emmanuel, 2015).

\section{Communication}

Communication is defined as a transition or information transition and understanding using symbols together from one person or group to another party and those symbols can be either verbal or nonverbal (Ivancevich \& Matteson, 1980). Judge (S. Robbins \& Judge, 2009) redefined communication as a relationship or interaction between superiors and subordinates (downward communication) or from the subordinates to superiors (upward communication) or among fellow workers (horizontal communication) and or communication across channel in order to achieve organizational or individual goal. (Muharto, 2014), Communication in an organization consists of instructions, reports, questions and petition. (Hofstede et al., 2010), argues that an inter-personal communication can be effective if consists of five things, namely openness, empathy (feeling what others feel), support (agreeing), positivity and similarities. The indicators of communication include:

- Togetherness within a school/Organization.

- Trust to transfer values.

- Discipline to implement

- Imposing sanctions for those violating the rules, values, norms.

- Working spirit as a form of practicing the culture.

\section{Coaching}

In general, coaching is about building relationships that help between coaches and individuals with whom the trainer is involved (defined as trainees in this study). One important principle emphasized in coaching is the idea that individuals have the ability to find solutions to their problems through increased awareness with the help of a coach (Grant, 2006; Moen \& Kvalsund, 2008; Whitmore, 2002). Although various definitions of coaching have been delivered, there are several agreements regarding the core of training practices, and most definitions have agreed that coaching is a process that involves a series of interactions (Bono, Purvanova, Owler \& David, 2010).

The use of coaching in organizations, whether it is business, leadership or executive training, has grown substantially into established practices in a number of organizations and continues to evolve Joo (2005). It is used in organizational settings to improve the performance of employees, teams and organizations in a number of ways, including but not limited to: helping to streamline learning in organizations, planning success and career planning, for job satisfaction, flexibility, interpersonal relationships, and leadership and management skills Williams (2005).

According to ICF (2012), coaching is the act of partnering with clients in a process to inspire creative thinking so that an individual can maximize his personal and professional potential.Swanson \& Holton (2009) suggest that the development of human resources (HR) can be defined as a process of developing and exploring the potential of individuals for the purpose of improving the performance of individuals, teams, work processes, and organizational systems. In line with Brown and Grant (2010), coaching focuses on goals and not on processes and the lack of references to improve performance is placed in several ways to distinguish group coaching. One of the main reasons for using the coaching approach is to improve performance (CIPD, 2010).

The work team perceives that coaching helps team members to explore issues that they will not discuss individually but together. This process helps the team to get to know each other more deeply. It removes protective barriers, open vulnerabilities, feelings and concerns. (Woodhead, 2011). The work team will look at each other outside of a professional role that allows team members to see the other side of their teammates (Black \& Westwood, 2004). In his findings Woodhead (2011), the use of coaching on the work team as an 
appropriate intervention in helping the team to work more effectively. Coaching is a learning facilitator method provided by organizations that allows employees to learn and improve performance (Ellinger et al., 2010). Coaching is different and is constantly updated because coaching contains strategies directed by the team itself and allows collaboration, and teamwork depends on steering driven by the team itself (Boyatzis et al., 2012). In the coaching process, the work team is guided and stimulated to be active in learning by focusing on solutions and seeking positive solutions. (Moen \& Federici, 2012)

\section{Training Need Analysis (TNA)}

It is not an easy task to train employees effectively. Training is an investment and the importance of training is still not seen by some organizations (Bliss, 2014). Some of the research that has been carried out recognizes the importance of training where organizations can be developed and can improve the profitability of their organizations. (Sung et al, 2014; Tharenou, 1991). Tung-Chun (2001) also agrees that educated and trained employees are a prerequisite for organizations to facilitate the knowledge and skills of employees very important for the success of job performance (Noe, Hollenbeck, Gerhart, and Wright, 2008). The TNA process continues where the performance of each employee is assessed to determine whether he is performing according to standards. If there is a difference, the TNA Process for deciding whether or not training can be used to close the gap (Jamil \& Som, 2016).

\section{Research and Methodology}

In this study the quantitative approach is used. Research respondents from the same company were a teamwork consisting of 15 employees. The data collection techniques used in this study were observation, interviews, and questionnaires.

The research that uses this quantitative approach is to examine the effect on teamwork before and after the treatment is given, to see if there are significant differences in the teamwork given the coaching treatment. Research respondents are employees of one of the small companies engaged in the chemical sector in Indonesia (Jakarta).

\section{Measuring Instruments}

The data collection techniques used in this study were observation, interviews, and questionnaires. The data used to be tested is with the results of the last key performance indicators (KPI) and three months after giving treatment, especially in the part of cooperation or group work.

Tabel 1: Before \& After KPI Values

\begin{tabular}{|cll|}
\hline & & \\
\hline & & \\
Respondent & Before & After \\
\hline & & \\
\hline 1 & 68 & 70 \\
\hline 2 & 56 & 64 \\
\hline 3 & 64 & 72 \\
\hline 4 & 48 & 62 \\
\hline 5 & 52 & 68 \\
\hline 6 & 44 & 60 \\
\hline 7 & 60 & 76 \\
\hline 8 & 72 & 72 \\
\hline 9 & 56 & 74 \\
\hline 10 & 64 & 66 \\
\hline 11 & 68 & 74 \\
\hline 12 & 52 & 68 \\
\hline 13 & 72 & 74 \\
\hline 14 & 60 & 66 \\
\hline 15 & 44 & 62 \\
\hline
\end{tabular}

\section{Statistical Analysis}

The data analysis technique in this study used descriptive statistical methods and Paired-Samples T Test to see whether there were differences before and after the coaching technique was given. 


\section{Result and Discussion}

Results that can be seen in Table. 2, shows that the average before and after giving coaching techniques. Before giving the coaching technique the results obtained were 58.67, while after the coaching technique was given the results showed an average of 68.53 . The test results also show that the correlation between the two variables is 0.731 with a significance of 0.002 . This shows that the correlation between before and after the coaching technique shows a strong and significant difference.

Table 2: Paired Samples, Statistic, Correlations and Test

\begin{tabular}{|c|c|c|c|c|c|c|c|}
\hline & Mean & $\mathrm{N}$ & Std. Deviation & Std. Error Mean & Correlation & Sig. & Sig. (2-tailed) \\
\hline Before & 58.67 & 15 & 9.401 & 2,427 & & & \\
\hline Pair & & & & & .731 & .002 & .000 \\
\hline After & 68.53 & 15 & 5.097 & 1,316 & & & \\
\hline
\end{tabular}

The resulting probability value is 0,000 (see Table.2). Because of the significant value (2-tailed) $<0.05$, it can be concluded that before and after coaching techniques were used, the values showed significant differences. Thus providing coaching techniques influences the team's performance results significantly.

\section{Discussion}

The results of this study are in line with previous studies conducted by several researchers. Strong relationships were obtained from the results of this study. In their research and findings, Haug \& Enz (2011) stated that coaching techniques play an important role in accelerating the formation of positive groups and achieving maximum group performance. In line with the statement of Owsukowska \& Pindelski (2010), where it is said that coaching techniques allows groups to get better results and is also proven in improving efficiency and management in groups. Reinforced again by the findings of Woodhead (2011), which shows that coaching techniques support work groups in improving communication, providing focus and clarity of shared goals, increasing trust and collaboration as well as approaches to problem solving, decision making and commitment to achieving shared results. The use of Coaching techniques in groups helps develop personal and interpersonal relationships as well as group dynamics because it breaks down barriers, creates a sense of belonging and deep empathic understanding with each other. From what we have found in this study, we recommend further research using larger and different groups or teams. This study also contributes to the literature of local studies on human resource development, specifically in the field of coaching. A number of studies in related fields can be found in studies that have been conducted globally, as a comparison. There are not too many studies that focus on coaching and not many of them pay attention to the possibility that coaching can also contribute to teamwork.

\section{Conclusion}

Establishing a reliable working group within an organization is not something that can be ignored. To be able to provide and get the desired results of each organization, it is inseparable from the ability of the resources available in it. To achieve all that, a working group works no longer as an individual. With working group a goal will be achieved faster than individual work. However, organizations must have a working group that can be relied on rather than just an ordinary working group. Coaching techniques are not new in the world of work. The approach to coaching techniques will be more easily accepted by each individual including the people who are members of the working group. The approach to coaching techniques can improve performance, communication, respect for others, and will get solutions to problems. Giving coaching techniques to working groups is the right decision to improve performance and get maximum results. However, keep in mind that giving coaching techniques is not just an understanding, but in practice that is how working groups can apply it in their daily works, especially in group works. In this study significant differences were obtained in the results of the achievement of the group that received and practiced coaching techniques, while still observing group work over the next three months. This study also contributes to the literature of local studies on human resource development, specifically in the field of coaching. A number of studies in related fields can be found in studies that have been conducted globally, as a comparison. There 
Aldrin \& Utama / International Journal of Research in Business and Social Science,

Vol 8 No 3, Special Issue, 2019 ISSN: 2147-4486

are not too many studies that focus on coaching and not many of them pay attention to the possibility that coaching can also contribute to teamwork.

\section{Acknowledgement}

This research received no external funding and the author declares no conflict of interest.

\section{References}

Aichouni, M. (2005). Organizational Behaviour. 10th Edition, NY: McGraw-Hill, Inc.

Alghamdi, A., \& Bach, C. (2018). Developing Teamwork at Workplace, International Journal of Business and Management Invention (IJBMI), 7(2), 28-40.

Benrazavi, S. R., \& Abu, D. S. (2013). Employees Job Satisfaction and Its Influence on Willingness to Work in Teams Universiti Putra Malaysia, 14(2004), 127-140. Journal of Management Policy and Practice Vol.. 14(1) 2013.

Black, T. G. and Westwood, M. J. (2004). Evaluating the Development of A Multidisciplinary Leadership. Leadership \& Organization Development Journal, Vol. 25 Issue: 7, pp.577591, https://doi.org/10.1108/01437730410561468

Bliss, C. J. (2014). Capital Theory And The Distribution Of Income (Vol. 4). Elsevier.

Bluckert, P. (2005). The similarities and differences between coaching and therapy. Industrial and Commercial Training, 37(2), 91-96. http://doi:10.1108/00197850510584241

Bono, J.; Purvanova, R.K.; Owler, A.J.; David, B. (2009). A survey of executive coaching practices. Personnel Psychology, 62(2): 361-404. http://doi.org/10.1111/j.1744-6570.2009.01142.x

Boyatzis, R. E., Smith, M. L., \& Beveridge, A. J. (2012). Coaching with compassion: Inspiring health, wellbeing, and development in organizations. The Journals of Applied Behavioral Science. 49(2), 153178. http://doi: $10.1177 / 0021886312462236$

Brown, S.W. and Grant, A.M. (2010). From GROW to GROUP: theoretical issues and a practical model for group coaching in organisations', Coaching: An International Journal of Theory, Research and Practice, 3(1), 30-45

Bruce, J. A., \& Ricketts, K. G. (2008). Where's All the Teamwork Gone? A Qualitative Analysis of Cooperation between Members of Two Interdisciplinary Teams. Journal of Leadership Education, 7(1), 65-75.

Cascio, W. F. (2010). Managing Human Resources: Productivity, Quality of Work Life, Profits. Work, xxxi, 719. Retrieved from http://www.amazon.co.uk/Managing-Human-Resources-ProductivityQuality/dp/0072987324

CIPD. (2010) Annual Survey Report 2010: Learning And Talent Development Survey, London: Chartered Competitive Advantage, 6th Ed. Mc Graw Hill Companies Inc., New York.

de Graaf-Zijl, M. (2012). Job satisfaction and contingent employment. Economist. 160(2), 197-218. https://doi.org/10.1007/s10645-011-9180-7

Delarue, A. , Van Hootegem, G. , Procter, S. and Burridge, M. (2008), Teamworking and organizational performance: A review of survey-based research. International Journal of Management Reviews, 10: 127-148. doi:10.1111/j.1468-2370.2007.00227.x

Dolot, A. (2018). Coaching Process And its Influence on Employees' Competencies in the Hospitality Sector - Case Study. International Journal of Contemporary Management, 2017, 75-98. doi:http://dx.doi.org/10.4467/24498939IJCM.17.011.7524

Ellinger, A. D., Ellinger, A. E., Hamlin, R. G., \& Beattie, R. S. (2010). Achieving improved performance through managerial coaching. In R. Watkins \& D. Leigh (Eds.), Handbook of improving performance in the workplace, Volume 2: Selecting and implementing performance interventions (pp. 275-298). San Francisco, CA: Pfeiffer/International Society for Performance Improvement. 
Aldrin \& Utama / International Journal of Research in Business and Social Science,

Vol 8 No 3, Special Issue, 2019 ISSN: 2147-4486

Emmanuel, O. B. (2015). The impact of teamwork on employee performance, (November).https://doi.org/10.13140/RG.2.1.4959.8804

Fahn, M., \& Hakenes, H. (2017). Department Of Economics. Johannes Kepler University of Linz. Teamwork as a Self-Disciplining Device by

Gallie, D., Zhou, Y., Felstead, A., \& Green, F. (2009). Teamwork, productive potential and employee Welfare.https://ora.ox.ac.uk/objects/uuid:8fa4cc2c-96d6-4e69-bc2d-

4eafa1875df2/download file?file format=pdf\&safe filename=Teamwork $\% 252 \mathrm{C} \% 2 \mathrm{Bprod}$ uctive\%2Bpotential\%2Band\%2Bemployee \%2Bwelfare\&type of work=Research+paper

Mustafa, G., Glavee-Geo, R., \& Rice, P. (2017). Teamwork orientation and personal learning: The role of individual cultural values and value congruence. SA Journal of Industrial Psychology, 43, 13 pages. doi:https://doi.org/10.4102/sajip.v43i0.1446

Grant, A. M. (2009). Workplace, executive and life coaching: An annotated bibliography from the behavioural science and business literature. Coaching Psychology Unit, University of Sydney, Australia.

Grover, S., \& Furnham, A. (2016). Coaching as a developmental intervention in organisations: A systematic review of its effectiveness and the mechanisms underlying it. PloS one, 11(7), e0159137.

Hanaysha, J. (2016). Testing the Effects of Employee Empowerment, Teamwork, and Employee Training on Employee Productivity in Higher Education Sector, International Journal of Learning and Development. 6(1), 164-178. http://doi.org:10.5296/ijld.v6i1.9200

Hofstede, G., Hofstede, G. J., \& Minkov, M. (2010). Cultures and Organizations: Software of the Mind, Third Edition. McGraw-Hill Education; 3rd edition. https://doi.org/10.2307/2393257

House, R. J., \& Mitchell, T. R. (2007). Path-goal theory of leadership. In Leadership: Understanding the dynamics of power and influence in organizations (2nd ed.). (pp. 241-254). https://doi.org/10.1177/014920639301900407

International Coach Federation (ICF) (2012). https://coachfederation.org/about

Ivancevich, J. M., \& Matteson, M. T. (1980). Optimizing human resources: A case for preventive health and stress management. Organizational Dynamics, 9(2), 5-25. https://doi.org/10.1016/00902616(80)90037-6

Ives, Y. (2008). What is "coaching"? An exploration of conflicting paradigms. International Journal of Evidence Based Coaching and Mentoring, 6(2), 100-113.

Jamil, R., \& Som, H. (2016). Training Needs Analysis: Practices of Top Companies in Malaysia International Review of Business Research Papers Training Needs Analysis: Practices of Top Companies in Malaysia, (February).

Jiang, X. (2010). How to Motivate People Working in Teams. International journal of business and management, 5(10), 223.

Joo B-K (Brian). (2005). Executive Coaching: A Conceptual Framework From an Integrative. Review of Practice and Research. Hum Resour Dev Rev 2005; 4: 462-488.

Kaplan, R.S. and Norton, D.P. (1996) The Balanced Scorecard-Translating Strategy into Action. Harvard Business School Press, Boston.

Kauffeld, S. (2010). Nachhaltige Weiterbildung. Betriebliche Seminare und Trainings Entwickeln, Erfolge

Kauffman C, Coutu D. (2009). The Realities of Executive Coaching. Havard Business Review: HBR

Kioko, F. (2018). An Evaluation of the Role of Teamwork on Employee Performance at Machakos County Government, Kenya, 5(1), 55-61.

Kosteas, V. D. (2011). Job satisfaction and promotions. Industrial Relations, 50(1), 174-194. https://doi.org/10.1111/j.1468-232X.2010.00630.x 
Aldrin \& Utama / International Journal of Research in Business and Social Science, Vol 8 No 3, Special Issue, 2019 ISSN: 2147-4486

Landeo, C. M., and K. E. Spier (2015). Incentive contracts for teams: Ex- perimental evidence. Journal of Economic Behavior \& Organization, 119, 496 - 511.

Lazear, E. P., and K. L. Shaw (2007): Personnel Economics: The Economist's View of Human Resources. Journal of Economic Perspectives, 21(4), 91-114.

Literature. In Grant, A. M., \& Stober, D. R. (Eds.). Evidence Based Coaching. NJ: Wiley \& Sons.

Mbinya, M. E. (2013). Factors Affecting Teamwork In Export Processing Zones in Kenya: A Case of indigo Garments Export Procesing Zone LTD (Master's dissertation, Kenyatta University).

Messen, Transfer Sichern(2010) Sustainable Education. Development of Organizational Trainings, Evaluation of Success, and Ensurance of Training Transfer. Berlin: Springer Verlag.

Mihalcea, A. (2014). Leadership, Personality, Job Satisfaction and Job Performance. Procedia - Social and Behavioral Sciences, 127, 443-447. https://doi.org/10.1016/j.sbspro.2014.03.287

Moen, F., \& Federici, R. A. (2012). The Effect from Coaching Based Leadership, 1(2). https://doi.org/10.5539/jel.v1n2p1

Moen, F., \& Kvalsund, R. (2008). What communications or relational factors characterize the method, skills and techniques of executive coaching. Journal of Coaching in Organisations, 6(2), 102-123.

Muharto, T. (2014). Perilaku organisasi. In Tangerang Selatan: Universitas Terbuka (p. 6.38-40).

Mullins, L.J. (1996). Management and Organizational Behaviour, 4th edition. London: Pitman.

Noe, R., Hollenbeck, J., Gerhart, B., and Wright, P. (2008). Human Resource Management: Gaining a

Norton, 1996, Harvard Business School Press).pdf. Proceedings of the IEEE. Research and Practice, 3(1),30 -45 .

Robbins, S. T., Judge, T. a, \& Hasham, E. S. (2009). Organizational Behavior. Pearson Education Limited.

Robbins, S., \& Judge, T. (2009). Organizational Behaviour: Concepts, Controversies, Applications, Development.

Rousseau, D. M. (1997). Organizational Behavior in the New Organizational Era. Annu. Rev. Psychol, 48,

Ruffus (1998). The Empowerment Process: Integration Theory and Practice. Academy of Management Journal, 13 (3): 471-482.

Salas, E., Tannenbaum, S. I., Kraiger, K., and Smith-Jentsch, K. A. (2012). The Science of Training and Development in Organizations: What Matters in Practice. Psychol. Sci. Public Interest 13, 74-101. doi: $10.1177 / 1529100612436661$

Snell, S., \& Bohlander, G. (2011). Managing Human Resources. IEEE Engineering Management Review. https://doi.org/10.1109/EMR.2008.4490144

Sung, S. Y., \& Choi, J. N. (2014). Do Organizations Spend Wisely on Employees? Effects of Training and Development Investments on Learning and Innovation in Organizations. Journal of organizational behavior, 35(3), 393-412.

Swanson, R.A. and Holton, E.F. (2009). Foundations of Human Resource Development. 2nd Edition, BerrettKoehler, San Francisco.

Tharenou, P. (1991). Managers' training Needs and Preferred training Strategies. Journal of Management Development, Vol. 10, No. 5, pg. 46-59.

Tung-Chun Huang (2001). The relation of training practices and organizational performance in small and medium size enterprises. Education \& Training. 43(8/9), 437 - 444.

Whitmore, J. (2002). Coaching for Performance. Growing People, Performance and Purpose (3 $3^{\text {rd }}$ eds.). London: Nicholas Brealey Publishing. 
Aldrin \& Utama / International Journal of Research in Business and Social Science,

Vol 8 No 3, Special Issue, 2019 ISSN: 2147-4486

Williams S, Offley N. (2005). Research and reality: Innovations in coaching. London: NHS Leadership Centre.

Woodhead, V. (2011). How does coaching help to support team working? A case study in the NHS, (5), 102-119.

Wu, M., \& Chen, Y. H. (2014). A Factor Analysis on Teamwork Performance: An Empirical Study of InterInstituted Collaboration. Eurasian Journal of Educational Research, 55, 37-54. 